\title{
Law Protection in Contract Agreement : PT. Telkom with IndiHome Cable Television Customer Service
}

\author{
Dio Prakoso ${ }^{1}$, Budi Santoso ${ }^{2}$, Rinitami Njatrijani ${ }^{3 *}$ \\ \{dio.prakoso@gmail.com¹, budisantosotmg@lecturer.undip.ac.id ${ }^{2}$, rinitami@live.undip.ac.id ${ }^{3}$ \}
}

Fakultas Hukum, Universitas Diponegoro, Jl. Prof. H. Soedarto, S.H., Semarang, Indonesia 50275 1,2,3

\begin{abstract}
IndiHome is the provider that receives the most complaints from the public, so consumers feel less satisfied with their services when compared to other providers. This study aims to determine: 1) Implementation of legal protection in the contractual agreement between PT. Telkom with IndiHome cable television broadcasting service customers, and 2) Responsibility of IndiHome in using cable television broadcasting services if the customer experiences a loss. The approach method in this research is empirical juridical, whether it is in accordance with the provisions of the Law of the Republic of Indonesia Number 8 of 1999 concerning Consumer Protection that applies or not. Analysis of the results of the study showed that; 1) legal protection in the contract agreement between PT. Telkom with the cable television service provider IndiHome, already contains an agreement regarding; Wi-Fi installation procedure; online and offline registration; IndiHome package fees; payment method; installation, and the contents of the agreement. However, in its implementation, PT. Telkom as the owner still often performs activities that are counterproductive to customer satisfaction; 2) the responsibility of PT. Telkom in the use of cable television broadcasting services if the customer suffers a loss is generally based on the Consumer Protection Act, where the responsibility has fulfilled consumer protection against interference.
\end{abstract}

Keywords: implementation of legal protection, IndiHome cable television broadcasting

\section{Introduction}

In line with the increasing needs of the community for the internet in addition to the speed and visual clarity that is increasingly needed, an internet service provider (ISP) has emerged for home as well as digital television, such as First Media, My Republic, Biznet Home, MNC Play, IndiHome Fiber, CBN and Indosat GIG. The rapid development of television technology encourages people to get information quickly. This makes television in Indonesia continue to grow, so that the emergence of pay television as mentioned above is considered a necessity.

Citizens as consumers who wish to become customers of the above providers are required to approve standard agreements that have been made by the provider as organizers or business actors. The agreement is a reciprocal agreement that basically raises the rights and obligations for both parties. Standard agreements made by business actors sometimes override the interests of consumers. This can be seen from the inclusion of standard clauses that are prohibited by the Consumer Protection Act contained in the agreement. Consumers who suffer losses due to the actions of business actors that are contrary to the agreement can make efforts to protect consumers, both through legal and non-legal channels. 
From several choices of internet and digital television providers in the city of Semarang, it is not uncommon to leave complaints to consumers because they feel they have been cheated. It is not uncommon for businesses to carry out operations often harming consumers. The loss that is often experienced by consumers is not only a unilateral change of the agreement, but also a service package that is not in accordance with the promotion, a onesided termination of program reduction without the information provided by the business actor. In the case of dispute resolution between business actors and consumers, the government facilitates the role of the Consumer Dispute Resolution Agency (BPSK) to organize the dispute.

One form of loss that is often experienced by consumers is not only unilateral change of agreements, but a package of services that is not in accordance with the promotion, termination unilaterally, reduction of the program without the information provided by business actors, so to follow up on it, it is necessary to supervise the actors effort. The lack of a role of the government towards business actors who have violated consumer rights, makes the business do not care about consumer rights. At present many business actors ignore consumers by taking decisions unilaterally, and harm consumers, without providing confirmation.

From interviews conducted with several consumers in South Semarang Sub-district, especially those living in Peterongan, Wonodri, Pleburan and Bulustalan, it is known that aspects that are often complained by consumers related to the use of cable television broadcasts include: reduction in the number of TV channels without prior notification from providers, the nominal amount of the bill which often exceeds the provisions, the information service package that is not in accordance with the promotion, the bill still appears even though the Wi-Fi network is no longer active and the cable television network has been unilaterally terminated. The phenomenon of consumer complaints above will take the case of the IndiHome provider, arguing that the IndiHome provider is the provider that receives the most complaints from consumers, as the results of a pre-survey conducted by researchers 2 (two) over the last 2 (two) months. Other cable television business providers, such as; Biznet, MNC Play and My Republic also accept consumer complaints, as experienced by IndiHome, but in terms of quantity and quality, IndiHome providers rank first in obtaining complaints from customers. The pre-survey was conducted 3 - 16 June 2019 in 4 (four) Kelurahans in South Semarang District, namely Peterongan, Wonodri, Pleburan and Bulustalan.

From the pre-survey results, it was obtained that during the last 1 (one) year, IndiHome was the provider that received the most complaints from customers, along with the relative length of time for repair services. Referring to this phenomenon, the writer is interested in conducting research by taking the title, "Implementation of Law Protection in Contract Agreement between PT. Telkom with IndiHome Cable Television Customer Service."

\subsection{Formulation of the problem}

The research problems proposed are:

1. How is the implementation of legal protection in the contract agreement between PT. Telkom with IndiHome cable television broadcasting service customers?

2. What is the responsibility of IndiHome in the use of cable television broadcasting services if the customer suffers a loss?

\subsection{Framework}


Almost all family members at home already hold an Android or iOS device as a means of communication and social media and surfing in all activities for the needs of school lessons, lectures or other social activities. Almost all of these mobile devices are equipped with various kinds of Wi-Fi to be able to connect to Wi-Fi networks both at public places, at home and in offices. From the start of the old Android phones that are usually equipped with $802.11 \mathrm{~b} / \mathrm{g} \mathrm{Wi}$ Fi standards to sophisticated mobile phones that are equipped with $802.11 \mathrm{ac}$ dual band wireless Wi-Fi standards.

In Indonesia, there are a number of telecommunications operators who are interested and ready to provide these services, and this shows that the draft regulation was made not because of being talkative to follow other countries, but rather because international trends are quite potential and that the readiness of providers in Indonesia has also enabled services its services. In this regulation, it is mentioned among other things, that the implementation of IPTV services aims to: encourage investment to spur broader telecommunications network infrastructure deployment; improve the efficiency of utilization of the existing local fixed cable network; spur the growth of the domestic content, hardware and software industry; increase social control and community participation through interactive services provided; accelerate the growth of electronic transaction services; provide information technology learning facilities; and restore the function of family togetherness in obtaining information and entertainment.

In the administration of IPTV services, the organizer must: protect the interests and security of the country; maintain and enhance morality and religious values and national identity; promote national culture; encourage the improvement of the people's economic capacity, realize equity, and strengthen the nation's competitiveness; anticipating technological developments and global demands; prevent ownership monopolies and support fair competition; conduct professionally and can be accounted for; and maintain a balance between technological development and social sensitivity.

In addition to the above objectives, this regulation also mentions several interesting things:

1. IPTV Provider is a consortium whose members consist of at least 2 Indonesian legal entities, and already has the licenses needed to provide IPTV services, namely Local Fixed Network Operation Permit, Multimedia Service License for Internet Access Services and Broadcasting Institution Subscribe.

2. Ownership of shares by foreign parties in Local Fixed Network Providers, Internet Service Providers (ISP), and Subscribed Broadcasting Institutions, which are members of a consortium must comply with the provisions of the applicable laws and regulations.

3. In case there are differences in the provisions of share ownership by foreign parties between the Local Fixed Network Provider, Internet Service Provider Multimedia Service Provider (ISP), and Subscription Broadcasting Institution, the ownership provisions are taken by foreign parties whose percentage is the smallest.

4. Whereas in the case of a legal entity incorporated in a Consortium but not included as a Local Fixed Network Provider, Internet Service Provider Multimedia Service Provider (ISP), or Subscription Broadcasting Institution, provisions on foreign ownership of shares in the legal entity must comply with the provisions of ownership by foreign parties as referred to above.

5. For broadcasting services (pushed services), the organizer must provide at least 10 percent of the channel's capacity to distribute domestic production content. 
6. For multimedia services (pulled services and interactive services), the organizer must provide domestic production content of at least 30 percent of its content library.

7. The number of domestic Independent Content Providers that contribute to the operation of IPTV services is at least 10 percent of the number of content providers in the content library owned by the Provider and is gradually increased to at least 50 percent within a period of 5 years.

8. The content as referred to above must comply with the provisions of the applicable laws and regulations. The Provider must guarantee that each Independent Content Provider which contributes to the operation of IPTV services has a license in accordance with the provisions of the applicable laws and regulations.

9. In the procedure for licensing, the consortium submits a written application to the Minister for permission.

10. The application must attach the following conditions: background; vision and mission; consortium member data; legality aspects (copy of legal documents for establishment of a consortium, copy of company establishment deed, and copy of Local Fixed Network Operation Permit, Internet Service Access Multimedia Service License, and Subscription Broadcasting Broadcasting Operation Permit); service aspects (type of service referred to in Article 9 that will be offered to customers and service development plans in the next 5 years).

11. It is required to attach the document content aspects for multimedia services (content sources; segmentation of target customers based on content; composition of domestic production content compared to all content; composition of production content of domestic Independent Content Providers compared to all content providers; and description of content excellence).

12. The technical aspects (commitment to the development of network infrastructure and services; commitment to provide network capacity to accommodate content contributions from independent content providers; commitment to develop facilities and infrastructure to support IPTV service activities; standards and technical specifications of the equipment system to be used, and the Internet Protocol Set-TopBox (IP-STB) standards and technical specifications to be used).

13. The other last aspect required in the application is the business aspect (business development plan; calculation of investment costs; capital adequacy; projected income and cash flow for the next 5 (five) years; projected number of customers within the next 5 (five) years adequacy of human resources, organizational structure of the consortium, and composition data of share ownership by foreign parties of each member of the consortium).

14. Other requirements that must also be attached to the submission of the application are a statement of ability to pay the fees charged by the state; statement of ability to fulfill contributions to the community; and bank guarantees of 5\% of the investment costs required in accordance with development commitments and are valid for a period of years.

15. The Minister shall examine the application requirements document within a maximum period of 15 working days after the application is received. Counting 30 working days after the inspection is complete, the Minister issues a principle permit for the operation of IPTV services for which the application is approved. Alternatively, within 30 working days after the examination of the request is complete, the Minister issues a letter of refusal of the request. 
16. Principle licenses are valid for 1 year and can be extended 1 time with a maximum validity of 1 year if the owner of the principle license has invested and carried out the development in accordance with the development commitments submitted in the application for an operating license.

17. During the validity period of the principle license, the organizer is prohibited from making changes to the required documents that have been submitted in the application for an operating license unless written approval from the Minister is in accordance with the applicable laws and regulations.

18. The owner of a principle license that is ready to provide IPTV services must submit an application for ULO to the Minister, where the ULO is carried out no later than 15 working days after the ULO application is received.

19. The owner of a principle license that has obtained an operation-worthy certificate has the right to submit a license for the operation of IPTV services, in which the operating license is issued by the Minister no later than 15 working days after the request for an operating license is received.

20. The operating permit is valid for 10 years and can be extended after going through the evaluation process, which must be submitted for an extension no later than 3 months before the validity period ends.

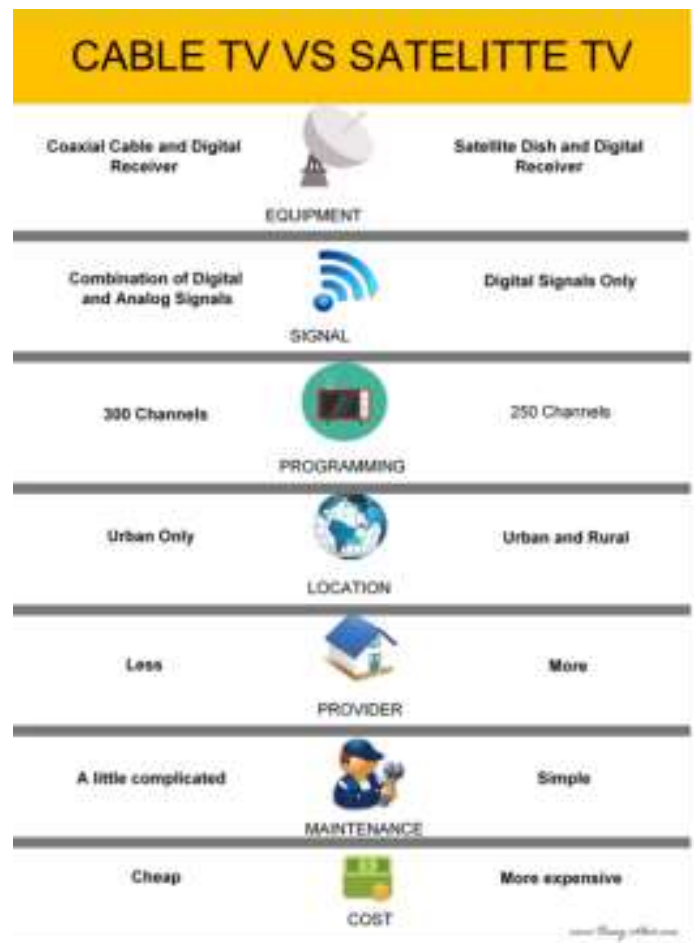

Figure 1. Comparison between cable TV and satellite TV 


\subsection{Research Method}

\subsubsection{Method of approach}

The approach method used in this research is empirical juridical. The research specification used in this legal research is analytical descriptive research. There are 2 (two) types of data in this study, primary data and secondary data

The data analysis method used in this study is a qualitative analysis method. Qualitative analysis method is intended as a data analysis that starts with descriptive data that is what has been stated verbally or in writing as well as real behavior that is researched and studied as something intact in qualitative use, especially in research used for requests for information that is explained in the form of description.

\section{Analysis of Research Results}

Contract agreement between PT. Telkom and the users of IndiHome cable television broadcasting services use standard clauses. Standard clauses are generally practical but not infrequently, the contents of the standard clauses are more focused on consumers, while regarding the responsibilities of business actors are eliminated or minimized. Definition of Standard Clause according to E.H. Hondius, as cited by Syahmin,[1] explained that the standard contract or standard clause is the concept of written promises that are prepared without discussing their contents, and generally stated in agreements that are not limited in number, but certain nature).

In contract law, the term standard clause is also called the "Exoneration Clause", where in Law Number 8 of 1999 concerning Consumer Protection [2] (hereinafter referred to as UUPK) it is also explained that what is meant by the standard clause is, "any rules or conditions and conditions terms that have been prepared and determined in advance unilaterally by business actors as outlined in a document and/or agreement that is binding and must be fulfilled by consumers."

At the bottom of the contract/agreement there are clauses consisting of several points containing additional information, the contents of which are as follows:

1. Willing to receive information from Telkom or Authorized Partners through various media including telephone, sms, email, and internet ads.

2. Willing to include IndiHome numbers in Telkom telephone directory and Telkom directory service 108

3. Agree that with the enactment of this IndiHome subscription contract document, the old subscription contract for telephone and or internet products and or Usee TV is considered no longer valid (specifically for customers upgrading services).

4. If the customer data on the contract to subscribe to telephone and or internet products and or Usee TV is different from the subscription contract for this IndiHome service, the customer who signs the IndiHome subscription contract is willing to be responsible for any risk of changes in the customer's data (specifically for customers upgrading services).

5. Customers will be charged a monthly rental fee Optical Network Terminal (ONT), STB and Platform, IPTV according to the type of STB used, each additional STB to 2 (two) and so on, will also be charged a monthly rental fee according to the type of 
STB and installation costs/settings (according to the prevailing installation conditions) that are billed the following month after the installation of the STB.

6. If the customer successfully subscribes, PT. Telkom will take Telkom's Customer Premises Equipment (CPE) device at the customer's address for IndiHome services

7. The amount of IndiHome bills, additional packages and ONT + STB rental can change at any time.

At the end of the contract, there is a provision that says, "I agree to be associated with all contract conditions of the IndiHome service subscription and declare that all written information is true."

Standard party clauses listed by business actors, as stated in Articles 12 and 13 of the agreement clause in the IndiHome service subscription contract transaction are very detrimental to consumers. The inclusion of the Raw Clause makes the position of consumers very weak/unbalanced in dealing with business actors. However, this does not mean consumers can not do anything. Like the article on www.ylki.or.id there is a lawsuit case of David Tobing (lawyer Anny R. Gultom, consumer) against PT. SPI (parking operator) that wins consumers. In the Judgment Verdict (PK) case No.124/PK/PDT/2007 submitted by PT. SPI, the Supreme Court even further strengthened the cassation decision, and rejected the Review filed by PT SPI. The Supreme Court decision requires parking managers to replace lost consumer vehicles in the parking area. More specifically, the decision of the Supreme Court No. 124 of 2007, which requires parking managers to replace lost consumer vehicles in the parking area. This Supreme Court (MA) decision automatically strengthens the position of Law No. 8 of 1999 concerning Consumer Protection concerning the prohibition of inclusion of standard clauses (Article 18), so that the standard clauses listed on each parking ticket become invalid or invalid.[3]

Winning the case above becomes concrete evidence of the irrelevance of the inclusion of a standard clause that transfers the responsibility of the business actor. This means that the Supreme Court and UUPK decisions can put pressure on parking managers who are trying to release responsibility. Likewise, the case affecting IndiHome consumers, as used as the topic of this thesis discussion, at least the Supreme Court decision above can be a reference for dispute with PT. Telkom, which unilaterally does not want to provide compensation to him. [4]

On the other hand, when there is a deviation from the standard clause in entering into an agreement and when there are parties who do not meet the legal requirements of the agreement, then legal consequences will apply.

1. Legal protection in the contract agreement between PT. Telkom, with the cable television service provider IndiHome, already contains an agreement regarding; a) Wi-Fi installation procedures, b) online registration, c) offline registration, d) IndiHome package fees, e) payment mechanism, f) installation, and g) contents of the agreement. From the administrative aspects of a standard agreement, it can be said that to meet the requirements in relation to consumer protection, only in its implementation, PT. Telkom as the owner of IndiHome still often performs activities that can lead to counterproductive emergence of customer satisfaction. From the several agreement clauses, aspects of inaction in responding to complaints of damage to the fiber optic fiber network and the termination of subscription contracts and dispute resolution, are the problems most often found in the community.

2. The responsibility of Telkom, in the use of cable television broadcasting services will apply only if the customer experiences a loss is generally based on the Consumer Protection Act. The responsibility of PT. Telkom to IndiHome consumers in the 
agreement to install Wi-fi experiencing internet network disruption is to fulfill consumer protection from internet network disruption as stipulated in Article 4 of Law Number 8 of 1999 concerning Consumer Protection. PT. Telkom is also responsible for carrying out Service Level Guarantee where Service Level Guarantee is Telkom's promise to consumers regarding maximum resolution time handling internet access network disruptions, where this document includes a description of service time and penalty services. This Service Level Guarantee is the whole business process of handling disruptions which constitutes an agreement between the people responsible for all activities in the business process for handling disruptions. However, in its implementation Service Level Guarantee, it is not always given properly by PT. Telkom, PT Telkom will be there when there is a disturbance beyond customer's ability. In this case, customer suffered a lot of material losses, because the customer's activities were disrupted, although in some cases PT. Telkom provides compensation in the form of a reduction in payment obligations each month, in accordance with the duration of the disruption.

\section{Suggestion}

PT. Telkom as a State-Owned Enterprise engaged in telecommunications must fulfill its rights and obligations to consumers. PT. Telkom, it should be able to fulfill all its responsibilities to consumers as a form of consumer protection in accordance with applicable laws and regulations. In this case, there are some suggestions so that in the future the quality of service from PT. Telkom through IndiHome can take place more optimally, namely:

1. The Government through the Ministry of Communication and Information and the Ombudsman Commission should always closely monitor internet service companies so that there are no more cases of delays in handling consumer complaints or accumulation of arrears of payments by customers resulting in the termination of internet services, because of the internet service termination policy that causes the most disadvantaged parties is a consumer.

2. Legal protection for IndiHome consumers based on Law Number 8 of 1999 concerning Consumer Protection granted by PT. Telkom might not be in accordance with the reality so IndiHome consumers know that their rights are protected and clearly know the responsibilities of PT. Telkom as a business actor. The role of the Government, entrepreneurs/associations and the community is also likely to help consumers in the problems experienced. So that IndiHome consumers are always loyal and comfortable using the IndiHome service.

\section{References}

[1] Syahmin, Hukum Kontrak Internasional. Jakarta: Rajawali Pers, 2005.

[2] Law Number 8 of 1999 concerning Consumer Protection. .

[3] I. Devita, "Klausula Baku VS Perlindungan terhadap Konsumen," 2012. [Online]. Available: https://irmadevita.com/2012/klausula-baku-vs-perlindungan-terhadap- 
konsumen/. [Accessed: 20-Nov-2019].

[4] H. A. Tuhumury, "Perlindungan Hukum Konsumen IndiHome atas Terputusnya Kabel Fiber Optik (fo) Milik PT. Telekomunikasi Indonesia. Tbk di Kota Jayapura," Leg. Plur. J. Law Sci., vol. 8, no. 1, pp. 15-37, 2018. 